蓲床 心タンポナーデを伴つた右心室粘液腫の 1 例

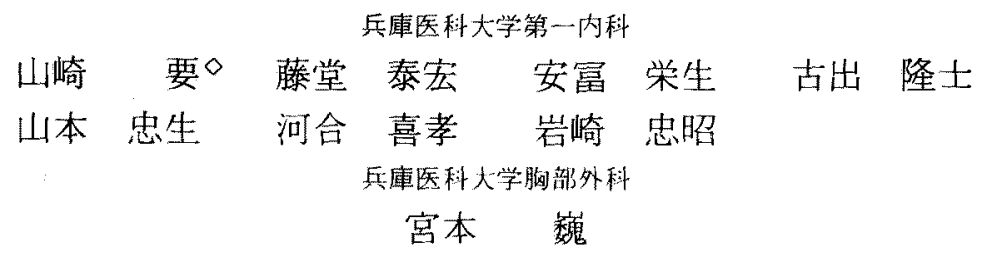

\title{
A CASE OF RIGHT VENTRICULAR MYXOMA WITH CARDIAC TAMPONADE
}

Kaname Yamasaki, MD, Yasuhiro Todo, MD, Nagao Yasutomi, MD, Takashi Koide, MD, Tadao Yamamoto, MD, Yoshitaka KawaI, MD and Tadaaki Iwasaki, MD

The First Department of Internal Medicine, Hyogo College of Medicine, Hyogo Takashi Miyamoto, MD

The Department of Thoracic and Cardiovascular Surgery, Hyogo College of Medicine, Hyogo

\begin{abstract}
概要 56 才, 男. 14 力前から徐々に増强してきた呼吸困難のため入院した、入院時全身の浮 腫, 著明な腹水詝留, 頝静脈怒張, 奇脈㐫認めた。心蔵聴診上第 2 肺動脈音の減弱之心基部で Levine 3/6度の全收縮期雑音を聴取した。検查で血沈値の俥度元進と軽い肝機能翼常を認めた。 胸部X線写真上心胸比は75\%で著明な心拡大があり，心電図でも右室肥大を認めた，Mモード 法心エコ一図で右室腔の抾大と右室流出路の異常エコ一像を認好, さらに多量の心膜液詝留, 右心不全, 低心拍出量の所見も認めた。它臓超音波断層図で右室流出路に $6 \times 3 \mathrm{~cm}$ の充実性腫溜 を認め，この腫瘤の移動の様子を詳細に知り得た，右心カテーテル検查と右房造影で右室王の 上昇，三尖升閉鎖不全と右室腔内の陰影欠損を認めた。以上より心タンポナーデを伴5右室内 腫場と崄断, 心膜穿刺で心タンポナーデの改善をはかり浮腫を軽快させてから手術による腫湯 の摘出に成功した。病理組織学的検查で粘液腫と診断した。右心室粘液腫は希な疾患で現在ま で34例の報告をみるにすぎず，本邦では 8 例目である，我々の症例の如く心タンポナーデを合 併した例は無い、腫湯による肺塞栓はしばしば見られる合併症で, 心臓カテーテル検查，心臓 血管造影，腫瘍の摘出術にあたり注意を要する。心䁍超音波断層法は単に安全で非観血的万法 といらのみにとどまらず腫䀛の形態や移動の様子を詳細に知り得る優れた検査法である。
\end{abstract}

心臟腫瘍は他臓器に発生した覀性腫瘍の転移に よるものが壬とんどで, 原発性のものは $0.000017 \%$ か50.03\% と言われ1), 非常に希であ る、しかるに近年の心臟血管系の検査法の進歩,

\section{[昭和 56 年 5 月16日受稿]}

本稿の概要は第96回日本内科学会近畿地方会（昭和 53 年 9 月9日)で報告した。
特に非観血的診断法である心臓超音波検查法の発 達普及とともに原発性心㺂腫場の報告例も増加し ている，原発性心臟腫湯の約半数は粘液腫である が，そのほとんどが心房内に発生し，心室内に発 生するのは希である”。この粘液腫は発生場所が 心房内でも，心室内でも，手術による根治が可能 であるから早期診断が特に重要である。

今回我々は著明な浮腫と腹水と心タンポナーデ 
を伴い心臓超音波断層法でその詳細を診断し得た 右心室粘液腫の 1 例を経験し, その摘出術に成功 したので報告する。

\section{症例}

患者： KU, 56才, 男, 無職.

主訴：呼吸困難.

家族歴： 特記事項無し.

既往歴：23才時に虫垂摘出.

現病歴：昭和 52 年 3 月頃から軽度の労作性呼 吸困難を自覚するようになり近医を受診, 心雑音 を指摘され心弁膜症の診断で時々投薬を受けてい た。昭和53年 1 月頃から咳嗽が多く出現するよう になつたが，感冒と思い放置していた，同年 3 月 から全身の浮腫と腹部膨満も出現し歩行が困難と なつた。 5 月中旬安静時にも強い呼吸困難を覚觉 るよらになり近医に入院，心タンポナーデの診断 を受け精查目的で昭和 53 年 5 月 17 日本院へ転院し た. 胸痛, 血痰, 発熱, 意識消失などの症状は無 かつた。

入院時現症：身長 $156 \mathrm{~cm}$, 体重 $57 \mathrm{~kg}$ 。栄養状 態は不良で全身, 特に下腿の浮腫と腹水貯留が著 明で腹囲は $89 \mathrm{~cm}$ であつた。 意識は清明であるが口 唇と爪床に軽度のチアノーゼがあり, 強膜に軽度 の黄疸を認めた。頝静脈は怒張し, 未梢静脈圧は $300 \mathrm{mmH}_{2} \mathrm{O}$ であつた. 脈拍数は95/分で整. 血圧は 呼気時 $114 / 84 \mathrm{mmHg}$, 吸気時 $100 / 84 \mathrm{mmHg}$ で奇脈 を認めた。呼吸数は $16 /$ 分, 肺肝境界は右鎖骨中線 上第 6 助骨。心濁音界は左縁が左前腋窩線，右縁 は胸骨右縁，上縁は第 4 肋骨であつた。心蔵聴診 上第 3 肋間胸骨左縁を最強点とするLevine $3 / 6$ 度 の全収縮期雑音を聴取し、第 2 肺動脈音が減弱し ていた。杂隹音の体位による変化や心膜摩擦音は 認めなかつた。呼吸音は清で肺野でラ音を聴取し なかつた，腹部は腹水のため著明に膨隆しており 肝腫大の程度はわからなかつた。

入院時検査成績： 検尿打よび検便は異常な ᄂ. 赤血球数 410 万 $/ \mathrm{mm}^{3}$, 血色素量 $13.6 \mathrm{~g} / \mathrm{dl}$, 、 マトクリット $40.8 \%$, 白血球数 $5100 / \mathrm{mm}^{3}$, 血沈值 1 時間 $32 \mathrm{~mm}, \mathrm{CRP} 3+$, 血清総蛋白 $6.0 \mathrm{~g} / \mathrm{dl}$, 血 清蛋白分画は alb $39.2 \%, \quad \alpha_{1}$-gl $6.0 \%, \quad \alpha_{2}$-gl
$10.7 \%, \beta-g l 14.3 \%, \gamma-g l 29.6 \%$, 総ビリルビン $2.85 \mathrm{mg} / \mathrm{dl}$, （直接型 $1.92 \mathrm{mg} / \mathrm{dl}$ ) GOT $62 \mathrm{KU}$, GPT $36 \mathrm{KU}$, アルカリフォスファターゼ3.6BLU, LDH 386U.

心膜液； 淡赤色, 軽度混濁, 比重 1.022 , 蛋白 $2.22 \mathrm{~g} / \mathrm{dl}$, 糖 $103 \mathrm{mg} / \mathrm{dl}$, 浸透止 $284 \mathrm{mOsm} / l$, 細胞 診パパニコロウ 3 度.

腹水；黄色, 透明. 比重 1.025 , 蛋白 $2.48 \mathrm{~g} / \mathrm{dl}$, 糖 $126 \mathrm{mg} / \mathrm{dl}$, 浸透圧 $283 \mathrm{mOsm} / l$, 細胞診パパニコ

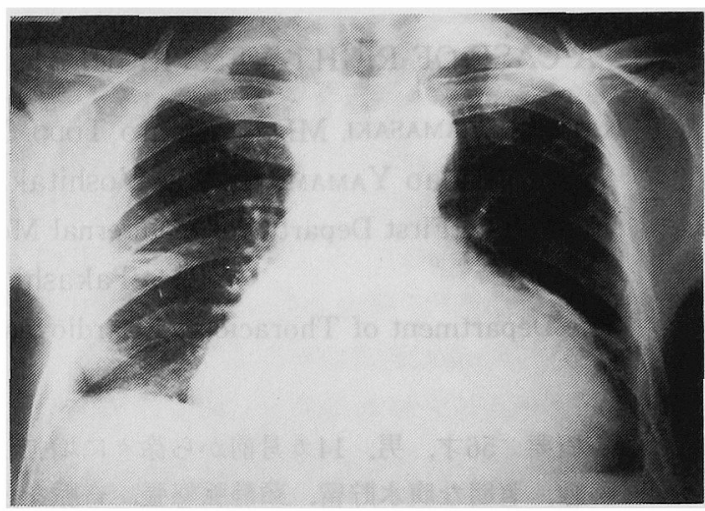

図 1, 胸部 X線写真
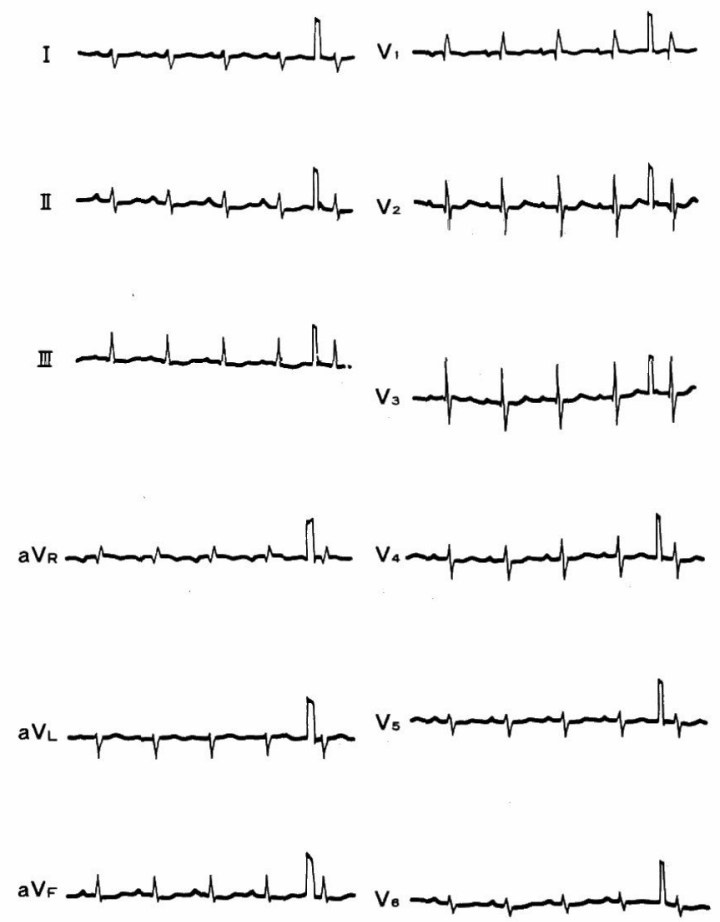

図2。心電図 
ロウ 2 度。

胸部レントゲン写真：図 1 に示したように心 胸比は75\%で著明な心拡大があり，右葉間胸膜腔 への胸水貯留を認めたが，肺野は明るく肺血流量 の減少が認められた。

心電図：図 2 のように洞調律で右軸偏位（十 $143^{\circ}$ ）と不完全右脚ブロックがあり右室肥大を認 めたが，低電位であつた。
Mモード法心ェコー図：図 3 に示した如く， 右室腔は著明に拡大し, 右室流出路に層状の異常 エコーを全心周期にわたり認めた。この異常エ コーは図4 にみられるよらに，高い胁間から記録 すると収縮後期にのみ三尖弁前方の右室腔内に認 められ，右室流出路の充実性腫瘤と考光られた。 三尖弁エコーは振幅が $23 \mathrm{~mm}, \mathrm{DDR}$ は $90 \mathrm{~mm} / \mathrm{sec}$ と正常範囲内であるが大きな $\mathrm{B}^{\prime}$-stepがあり右心

128559

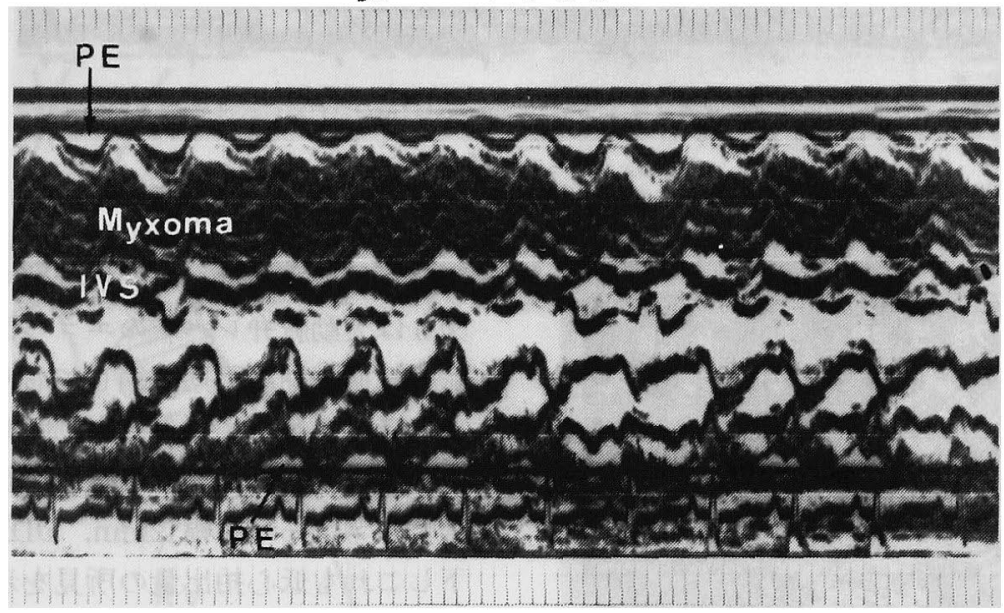

図3．心ェュー図（その1）

PE : 心膜液, IVS : 心室中隔.

Re 128559

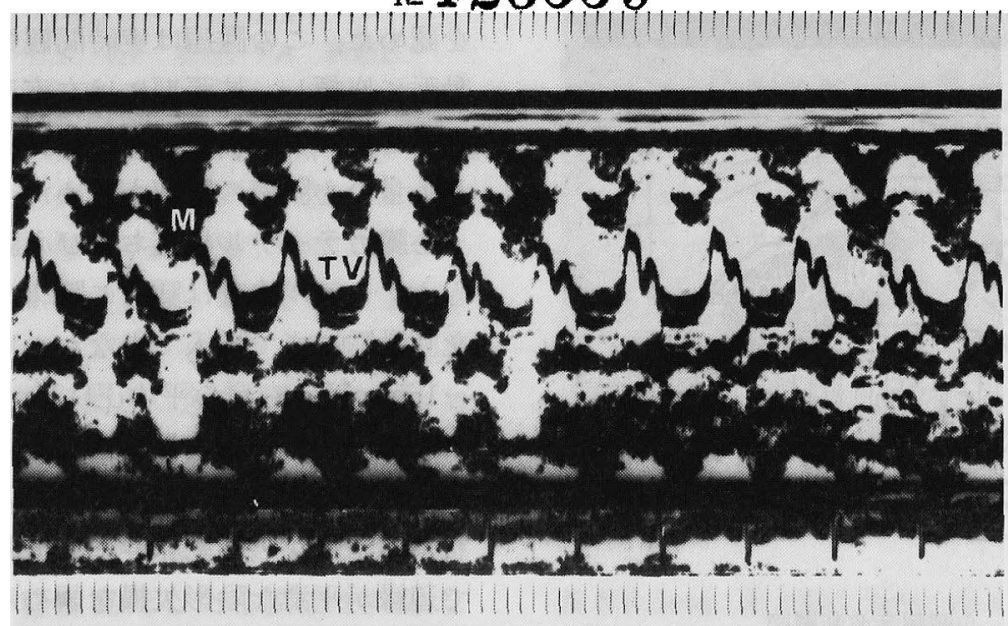

図 4。心エコ一図（その 2)

M：腫瘤，TV：三尖升. 


\section{9}

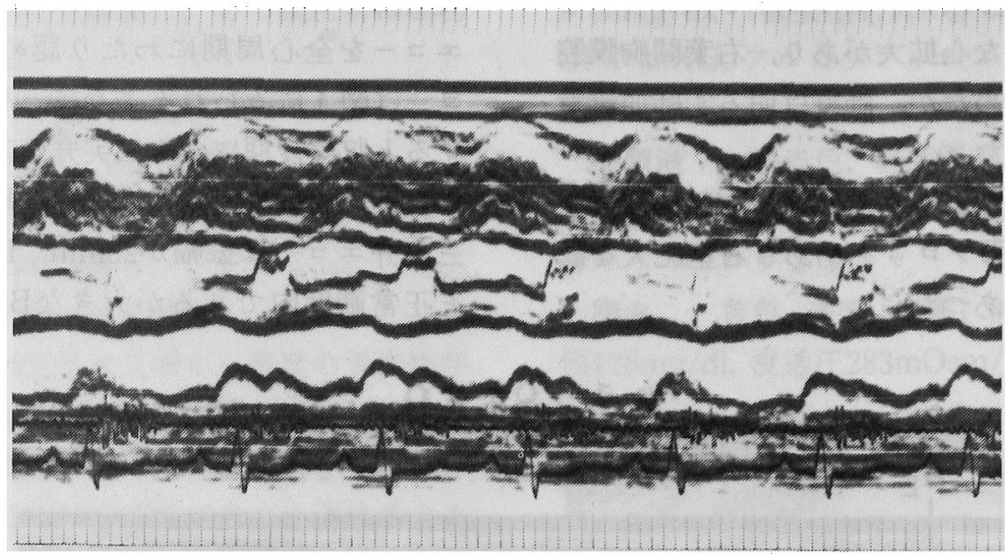

図 5。心ェュー図（その3）
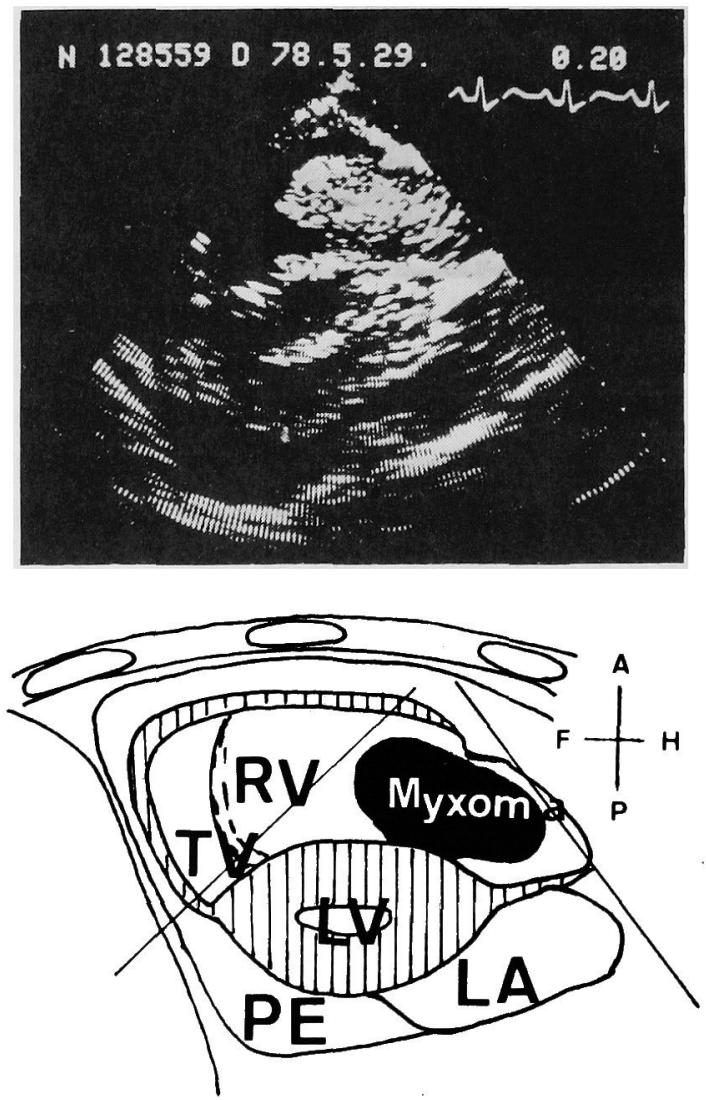

図6。心臓超音波断層図

$\mathrm{RV}$ ：右室, $\mathrm{LV}$ ：左室, $\mathrm{LA}$ ：左房, $\mathrm{TV}$ : 三尖弁, $\mathrm{PE}$ ： 心膜液, $\mathrm{A}$ ：胸側, $\mathrm{P}$ : 背側, $\mathrm{H}$ : 頭方, $\mathrm{F}$ ：足方.
不全が予想された。，心膜液貯留も顕著であつた。 図 5 は大動脈弁レベルのエコー図であるが, 大動 脈弁は拡張期に早期閉鎖して扣り低心拍出量のた めと考えられる.さらに大動脈弁の開放は吸気時 に小さい。これは奇脈を示す所見と考えられる。 僧帽弁エコーは振幅 $12 \mathrm{~mm}$, DDR $10 \mathrm{~mm} / \mathrm{sec}$ と低 下しこれも低心拍出量の所見を示している。

心臓超音波断層図；図 6 は右室流出路から左 室心尖にかける断面であるが，右室腔が拡大し， Mモード法心エコー図から推測された様に右室流 出路に限局し, $6 \times 3 \mathrm{~cm}$ の卵円形で, 充実性の腫瘤 を認めた。この腫瘤は実時間観察では収縮期に肺 動脈に嵌頓し, 拡張期には右室流出路に戻り, 可 動性を持つていることが確認された。さらにかな り多量の心膜液の貯留も認めた。

心臓カテーテル検査および心缄血管造影；右 心カテーテル検査は腫瘤に障害され, カテーテル を肺動脈にまで插入できなかつたが, 右室圧は78/ 〜 16 mmHg, 右房の平均圧は $18 \mathrm{mmHg}$ で, v波は28 $\mathrm{mmHg}$ り, 三尖弁閉鎖不全を認めた。図 7 は右 房造影図であるが，右房と右室の著明な拡大と， 右室流出路から肺動脈幹にまで及ぶひよらたん型 で辺縁が平滑な陰影欠損を認める。

臨床経過：以上の所見から右室腔内に腫瘤が 存在し，この腫瘤が収縮期に肺動脈幹に嵌頓する 

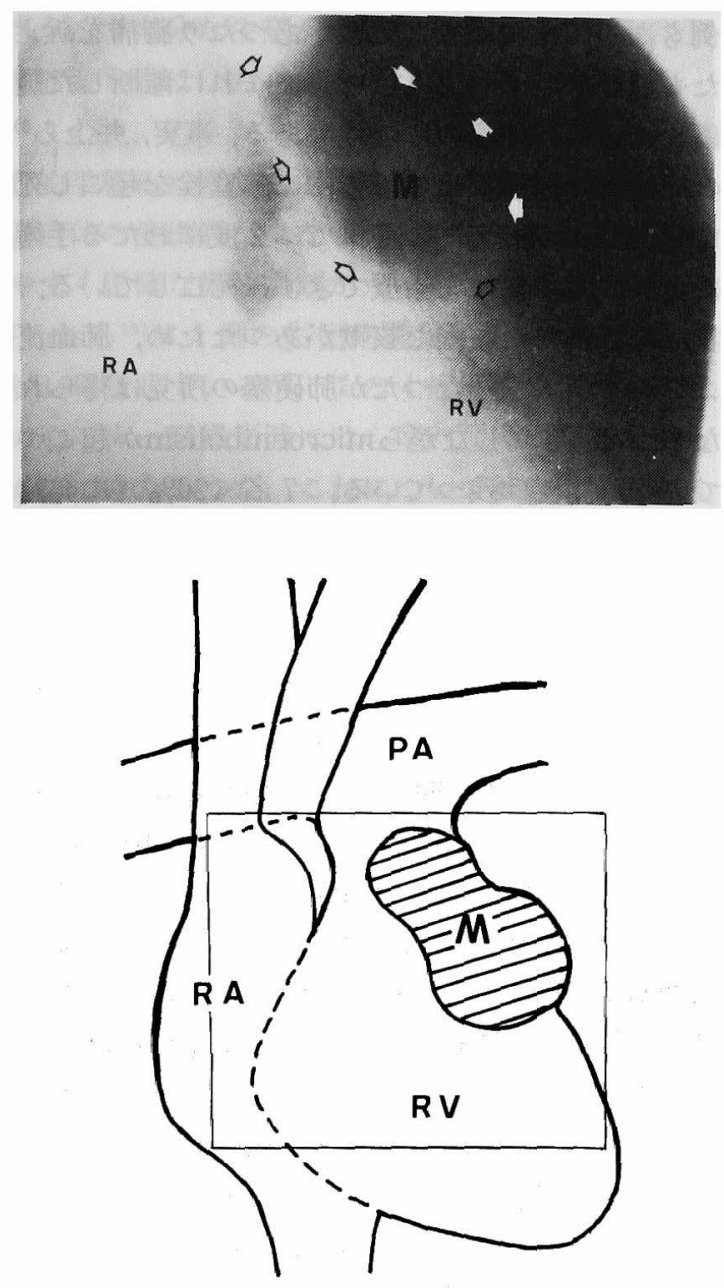

図 7.心臟血管写 (右房造影)

$\mathrm{M}$ : 腫瘤, RA：右房, RV : 右室, $\mathrm{PA}$ ：肺動脈.

ため, 肺動脈弁狭窄, 右室抎大, 三尖弁閉鑜不全, 低心拍出量を来し心タンポナーデを合併したもの と考光た、乙かし全身の浮腫と腹水貯留が顕著な ため，即刻手術にふみきることができず，心膜穿 刺で心タンポナーデを改善させるとともに，脱水 に注意しつつ利尿薬を使用し全身状態の改善をま つた。しかし血圧が下降しはじめたため，入院 2 週間後の昭和 53 年 5 月 31 日，手術を行なつた。手 術では心膜が著明に拡大していて心膜切開で約 $400 \mathrm{ml}$ の淡黄色で軽度混濁した心膜液を採取し た. 右室前壁の流出路に切開を加えたところ心室 中隔から発生した腫瘍が発見された。この腫瘍は

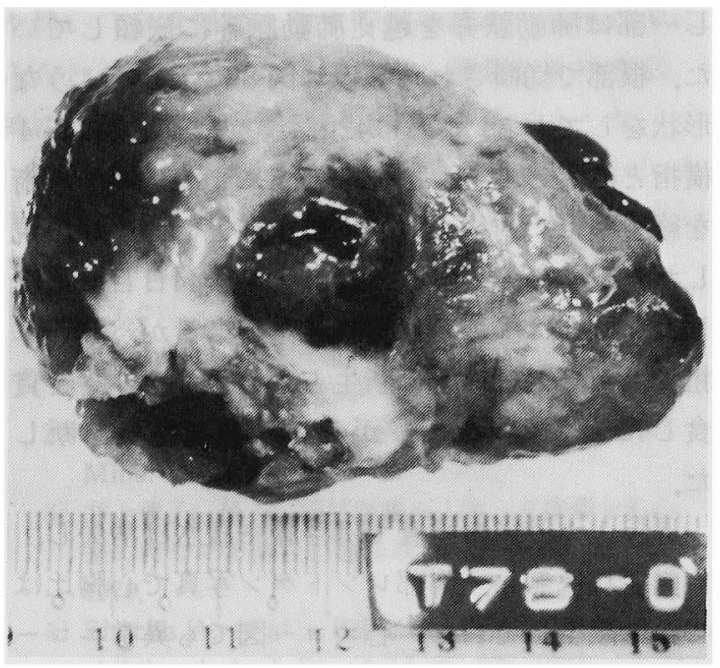

図 8. 摘出された粘液腫

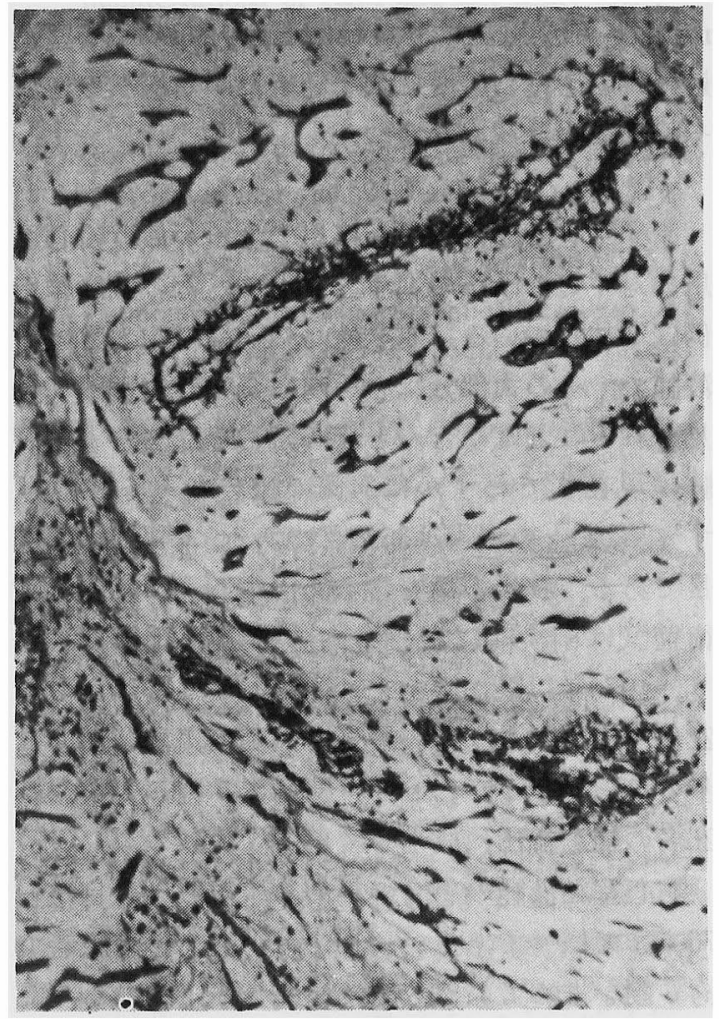

図 9.腫瘍の組織像

長さ $7.5 \mathrm{~cm}$, 最大幅 $3.5 \mathrm{~cm}$, 厚さ $4.5 \mathrm{~cm}$ でひようた 九型をして抒り，右心室前側壁から心室中隔に至 る部位から発生し，右室流出路を注注完に閉塞 
し一部は肺動脈升を越え肺動脈幹に嵌頓してい た。根部で切断された腫瘍は図 8 に示したような 形状をして扔り，重量は42gだつた。三尖升口が 4 横指と拡大していたので 2 横指にまで縫縮し手術 を終了した，術後一過性に肺水腫と低血圧が出現 したが，その後の経過は順調で術後44日目に退院 した。図 9 は腫瘍の病理組織像であるが, 間質は 粗で多数の毛細血管の新生と,へモジデリンを貪 食したマクロファージがみられ粘液腫と診断し た。

退院 1 カ月後の检查では浮腫や腹水は消失し， 自覚症状は無い，胸部レントケ゚ン写真で心胸比は 49\%に減少しており，心ェュー図でも異常ェコー 像や心膜液貯留認めていない，術後66日目に心 臓カテーテル検查を施行したが，右室殴は39/〜4 $\mathrm{mmHg}$, 肺動脈纴は32/14mmHgであつた. 右室造 影では右心室の軽度拡大を認めたが右房への逆流 や陰影欠損は認めなかつた。

\section{考案}

原発生心蔵腫瘍は希な疾患であるが最近の心疾 患に対する診断法の進歩とともに，その臨床報告 例は増加している. 原発性心臟腫湟の約半数は粘 液腫で，その大部分は心房内に発生し心室内に発 見されることは社とんど無い。さらに右心室粘液 腫は現在までわずかに34例の報告をみるにすぎ ず2 2 18), 我々の報告は35例目である。本邦では 8 例 目である。我々の例を含め35例中28例，80\%で手 術前又は剖検前に右心室内隀湟と彰断されて抒 り，1970年以降に限ると診断がつかなかつたのは 22例中 1 例にすぎず，最近の心䁍疾患診断法の進 歩の注どをらかがわせる．31名に手術が行なわれ 26名の腫瘍摘出に成功している。

右心室粘液腫の患者の年令は生後 2 力月目から 76才まで様々であるが，10才台と20才台の患者で 約 6 割を占めている。男女比は $2 ： 1$ である。 35 例の患者の症状を検討したところ18名 (51\%) に 呼吸困難が，8名(23\%) に失神発作が，7名(21\%) にチアノ一ゼがあつた。これらは右室流出障害に よると思われる、肺循環に続いて体循環も障害さ れチアノーゼ，意識消失，㾏孪が起こり死亡した
例もある、また頑固な咳嗽があつたり胸痛を訴え たものが 3 名ずつあり ( $9 \%)$ ，これは離断した盾 淘片による肺硬塞の可能性するる。事事, 井上ら ${ }^{3)}$ の症例では腫瘍摘出の手術中に肺塞栓を起こし死 亡し, Gonzálezら ${ }^{18)}$ の症例では 2 度にわたる手術 によつてす肺塞栓を治療できずに死亡している。 我々の症例でも頑固な咳濑があつたため，肺血流 シンチグラムを行なつたが肺硬塞の所見は得られ なかつた、しかしながら microembolismが起こつ ていた可能性は残つている，7名（20\%）に発熱 がみられ，当初細菌性心内膜炎を疑われた例も多 い，その㴗か三尖弁閉鎖不全に上ると思われる心 雑音や末梢の浮腫が存在したものが若干ある。し かしながら我々の症例の様に心タンポナーデを合 併した例はみられない，我々の症例では，高度の 右室流出障害が長期間続いたため右室腔の拉大が 起こり静脈王の上昇とリンパ液の還流障害が生 じ，これと低アルブミン血症とがあいまつて著明 な心膜液貯留が起こつたと考えられる. Kessler $5^{19)}$ 纴心エコ一図上心膜液貯留と右室腔拡大との 間には有意な相関があるが，その詳細な機序につ いては不明であると述べている。

心蔵聴診上肺動脈并狭窄症に類似した駆出型収 縮期雑音を聴取したり，第 2 心音の著明な分裂を 認めることがある。また心雑音が体位変換ととも に変化したり，畽瘍の移動に起因すると思われる 過㮃心音が存在することがある6)131.我々の症例て は三尖弁閉鎖不全による全収縮期雑音を聴取した が，体位変換による心雑音の变化は無く第 2 肺動 脈音は減弱していた。

心電図上右室肥大を認めることが多く，心房細 動や期外収縮などの調律異常を伴らこともある。 我々の症例でも右室肥大と一過性の wandering pacemakerの所見を認めた。

胸部レントゲン写真では左第 2 弓の乫出や明る い肺野を認めた例もあるが，多くは正常である。 希に石欧化した腫县像を認める。

心葴血管造影を行ない右室腔内に陰影欠損を認 めれば診断が確定するわけであるが，腫瘍片や睡 瘍表面の血栓の離断による肺硬塞を起こす危險を 
伴らので充分な注意が必要で，造影剤の注入は上 大静脈もしくは右心房内で行なうべきである゙”.

この点, 心ェコー図は非観血的で安全なため比 較的手軽るに行なるる検査法であるが，右室内腫 堭自体の症例数が少ないこともあつて見逃がされ やすく正確な葕前診断がつ汀られた例は少ない。 Portsら ${ }^{15}$ は 4 例の右室内腫湟の心エコー図を検 討し報告しているが，この 4 症例のいずれも初回 の心エコー因撮影時には心室内腫瘍の存在を明ら かにできなかつた。これについて彼らは右室が 4 心腔の中で最も前にあり，しかも胸骨の直下にあ るためその検索が困難なこと，右心室粘液腫は移 動性に富み収縮期には右室腔内よりむしろ右室流 出路にあることが多いので，右室腔の検索だけで は見逃がされる可能性があることを挙げ，右室腫 瘍の診断に際してMモード法心ェコ一図には限界 があるとしている.この点real-time, two-dimensional echocardiographyは腫瘍が動く様子や, 腫 湟茥の部位をも知ることができるので非常に有効 であると述べている、我々の症例では左室短軸で, 肺動脈弁口を含さ断面の心臓超音波断層図で腫場 の形態や動きをよく観察できたが，一般的に右室 全体を知るにはトランスデューサーを患者の左側 で，心尖部付近に置くことにより得られるapical four chamber viewが最も適していると考皇られ $ろ^{20)}$ 。このように心藏超音波検査で腫瘍に関する 充分な情報を得られれば，あえて心臓カテーテル 検查や心臓血管造影を行なら必要は無いと我々は 考えている.

粘液腫の摘出術後の経過は概ね良好であるが， 左心側の粘液腫の摘出術後に右心室粘液腫を再発 した例も2 例報告されて叔り ${ }^{5177}$, 術後経過を追う 必要がある。

\section{結語}

心タンポナーデを伴つた右心室粘液腫の 1 例を 経験した。全身の浮腫と腹水貯留が著明なため手 術時期の決定が困難であつたが，血圧が下降しは じめた段階で緊急手術を行ない腫瘦の摘出に成功 乙救命し得た。文献上本例は右心室粘液腫の35例 目にあたるが，本例の様に高度の心タンポナーデ
を伴い，全身浮腫と腹水貯留を認めた症例は他に みられない。本例の診断には心蔵超音波検查法， 特に心葴超音波断層法が非常に有用であつた。

謝辞 本症例の䛦断之治療にあたり御指導をいただいた 本学第一内科学教室教授 故 佐藤 進先生に澡謝いたし ま。。

\section{文献}

1) Heath D: Pathology of cardiac tumors. Amer J Cardiol $21: 315,1968$.

2) Donatelli R, et al: Sul "myxoma cordis". Minerva Cardioang 9:467, 1961.

3）井上律子, 他：心臓粘液畽の 1 例，主腫癉を右心 室に持つ大多発性心缄粘液腫。心缄 $2: 1157$, 1970.

4) Simcha A, et al: Primary cardiac tumors in childhood. Arch Dis Child 46: 508, 1971.

5) DeMaria AN, et al: Unusual echographic manifestations of right and left heart myxo. mas. Amer J Med 59 : 713, 1975.

6）和泉 徹，他：右心室粘液腫の 1 治験例。心臟 $7: 1527,1975$.

7) Snyder SN, et al : Diagnostic features of right ventricular myxoma. Amer Heart J 91: 240, 1976.

8) Geddes DM and Kerr IH: Case reports: Pulmonary arterial aneurysms in association with a right ventricular myxoma. Brit J Radiol $49: 374,1976$.

9) Dang CR and Hurley EJ : Contralateral recurrent myxoma of the heart. Ann Thorac Surg $21: 59,1976$

10）大久保正，他：右心室粘夜腫一 1 手術治験例なら びに文献的考察一。心蔵 $8: 73,1976$.

11) Nakata $K$, et al : Right ventricular myxoma in infancy. Jap Circul J 40:1183, 1976.

12) Sasaki $S$, et al: Primary intracavitary cardiac tumors. J Cardiovasc Surg 8: 15, 1977.

13) Chandraratna PAN, et al: Echocardiographic, angiographic, and surgical correlations in right ventricular myxoma simulating valvar pulmonic stenosis. Circulation $55: 619,1977$.

14) Nanda N, et al: Echocardiographic features of right ventricular outflow tumor prolapsing into the pulmonary artery. Amer J Cardiol 40 : 272, 1977.

15) Ports TA, et al: Echocardiography of right ventricular tumors. Circulation 56:439, 1977.

16) Roelandt $J$, et al : Ultrasonic demonstration of right ventricular myxoma. J Clinic Ultra. 
sound 5: 191, 1977.

17) Balk AHM, et al: Bilateral cardiac myxomas and peripheral myxomas in a patient with recent myocardial infarction. Amer J Cardiol $44: 767,1979$.

18) González A, et al: Massive pulmonary embolism associated with a right ventricular myxoma. Amer J Med 69: 795, 1980.
19) Kessler KM, et al: Echocardiographic observations regarding pericardial effusions associated with cardiac disease. Chest 78:736, 1980.

20) Henry WH, et al: Report of the American society of echocardiography comittee on nomenclature and standards in two-dimensional echocardiography. Circulation $62: 212,1980$. 